\title{
Charles Darwin and the scientific mind
}

\author{
Article
}

Accepted Version

Stack, D. (2019) Charles Darwin and the scientific mind. The British Journal for the History of Science, 52 (1). pp. 85-115. ISSN 0007-0874 doi:

https://doi.org/10.1017/S0007087418000973 Available at https://centaur.reading.ac.uk/72739/

It is advisable to refer to the publisher's version if you intend to cite from the work. See Guidance on citing.

To link to this article DOI: http://dx.doi.org/10.1017/S0007087418000973

Publisher: Cambridge University Press

All outputs in CentAUR are protected by Intellectual Property Rights law, including copyright law. Copyright and IPR is retained by the creators or other copyright holders. Terms and conditions for use of this material are defined in the End User Agreement.

\section{www.reading.ac.uk/centaur}

\section{CentAUR}

Central Archive at the University of Reading

Reading's research outputs online 


\section{Charles Darwin and the scientific mind}

David Stack*

\section{Abstract}

Although often presented as an essential, ahistorical, or innate psychological entity, the notion of a 'scientific mind' is ripe for historical analysis. The growing historical interest in the self-fashioning of masculine identities, and more particularly the selffashioning of the nineteenth century scientist, has opened up a space in which to probe what was understood by someone being said to possess a 'scientific mind'. This task is made all the more urgent by the recently revived interest of some psychologists in the concept and the highly gendered and culturally conditioned understanding of the scientific mind displayed in some contemporary debates. This article contributes to that task, and fills a rare gap in Darwin studies, by making the first detailed exploration of Charles Darwin's understanding of the scientific mind, as revealed in the psychological self-analysis he undertook in his 'Recollections of the development of my mind and character' (1876), and supplemented in his Life of Erasmus Darwin (1879). Drawing upon a broad range of Darwin's published and unpublished works, this article argues that Darwin's understanding of the scientific mind was rooted in his earliest notebooks, and was far more central to his thought than is usually acknowledged. The article further delineates the differences between Darwin's understanding and that of his halfcousin Francis Galton; situates his understanding in relation his reading of William Whewell and Auguste Comte; and considers what Darwin's view of the scientific mind tells us about his perspective on questions of religion and gender. Throughout, the article seeks to show that the 'scientific mind' is always an agglomeration of historically 
specific prejudices and presumptions, and concludes that this study of Darwin points to the need for a similarly historical approach to the question of the scientific mind today.

It is quite common, in reading and in conversation, to find references to the 'scientific mind', but it is difficult to ascertain precisely how this mental structure is supposed to differ from other sorts of mind. (J. W. N. Sullivan, 'The Scientific Mind', 1925)

The hesitancy of the science writer and journalist J.W.N. Sullivan (1886-1937) in defining the 'peculiar kind of mind called the scientific mind' was rooted in his discomfort with the role scientists had played in the First World War. The conflict, Sullivan argued, had shredded a 'common article of the Victorian scientist's creed': the notion that the scientific mind was necessarily moral or noble. This intimation of what Steven Shapin has called the "moral equivalence' of scientists and non-scientists combined for Sullivan with the ways in which he saw national characteristics inflecting scientific research, and led him to an implicit understanding of the scientific mind as a culturally conditioned construct, shaped by political events. ${ }^{1}$ This contextual awareness stands in contrast to the more straightforward 'traditional description of the scientific mind' expressed by another journalist who, writing 30 years earlier described it as 'calm, judicial, unemotional, [and] semi-sceptical towards all things until actually proved'. ${ }^{2}$ The contrast of late-Victorian certainty with interwar angst is hardly surprising, but it helps to highlight what ought to be an obvious point: the 'scientific mind' is not an essential, ahistorical, or innate psychological entity, but is a culturally sensitive construct, ripe for historical analysis. 
The term was certainly in use at the start of the nineteenth century. ${ }^{3}$ That flawed but beguiling research tool the Google ngram viewer suggests a rapid growth in usage from the early 1860 s, peaking in 1875, the year after the publication of Francis Galton's English Men of Science, followed by a slight dip, a period of uneven growth, a sharp rise up until an absolute peak in 1929, and a slower decline down to the year $2000 .{ }^{4}$ This pattern is probably much as we would expect from long-view commentaries on the reputation of science and scientists, such as that of Shapin, but clearly much more qualitative work is needed to establish both how usage of the term changed over time and how the 'scientific mind' aligned with, or can be distinguished from, other categories, such as 'men of science', 'scientific worker' or, perhaps more pertinently, 'philosopher' and 'genius'. The histories of these terms have already begun to be written and the stated objective of Joyce Chaplin and Darrin McMahon's work on genius, to treat 'genius as a historical concept, rather than a presumed transhistorical fact', offers an important example of how a history of the 'scientific mind' might be approached. 'Genius' and the 'scientific mind', however, were not synonymous. Chaplin and McMahon chart the rise of 'genius' as a general or universal quality against an earlier tradition in which 'one might possess a particular genius, or be ingenious in a particular field'. ${ }^{5}$ The growing nineteenth century use of the term 'scientific mind', with its implied exclusivity to a discrete specialism, suggests that this rise did not go unchallenged.

Perhaps one reason why historians have so rarely engaged directly with the term is its sheer slipperiness. As Sullivan noted, although used frequently, the term 'scientific mind' has rarely been defined explicitly, and even among psychologists has consistently failed to gain traction as an independent area of study. Gaston Bachelard's La formation de l'esprit scientifique (1938) encouraged the exploration of psychological factors in the development of the sciences, but it was not until 1966 that the phrase 'psychology of science' first appeared in an English language 
book title - Abraham H. Maslow's Psychology of Science - and another forty before G. J.

Feist's The Psychology of Science and the Origins of the Scientific Mind (2006) made the case for a distinct sub-discipline of psychology. Feist made the intriguing argument that the psychological study of the scientific mind had already emerged de facto, but unacknowledged, and that all that was needed was to synthesise existing work in neuroscience, developmental psychology, cognitive psychology, personality psychology, and social psychology, into a discrete empirical study of scientific thought and behaviour through the use of these new perspectives in biological, developmental, cognitive, personality, social, and clinical psychology. ${ }^{6}$ Feist failed to excite much interest among his fellow psychologists, and historians were never likely to be sympathetic to his ahistorical understanding of science as primarily a cognitive activity, rooted in an immaterial psychology. But one feature of Feist's work that ought to interest historians is the extent to which drew upon Darwin, both by using Darwin's autobiography as a case study and in order to situate the scientific mind within a broader evolutionary history. ${ }^{7}$ As we shall see, this dual approach was precisely how Darwin himself had approached the problem. Unpacking Darwin's formulation of the scientific mind, therefore, will make a contribution to a broader study - both historical and contemporary - of the cultural construction of the scientific mind.

The growing literature on the fashioning of scientific self in the second half of the nineteenth century has opened a space in which a detailed exploration of Darwin's understanding of his own scientific mind might be pursued. ${ }^{8}$ The work of Jan Golinksi, Ruth Barton, and Heather Ellis, among others, demonstrates the value of looking at how nineteenth century scientists understood and framed their own psychology. ${ }^{9}$ Barton's work, in particular, with its sensitivity to the hierarchical aspect of self-fashioning is especially helpful when considering Darwin's understanding of his own scientific mind. ${ }^{10}$ Yet despite the oft-lamented ubiquity of Darwin in 
studies of Victorian science, it is noticeable that he is relatively absent from much of the recent work on self-fashioning, barely meriting a mention in Ellis's Masculinity and Science (2017), for example. ${ }^{11}$ The two notable exceptions to this are Paul White's study of Darwin and emotions and Alexis Harley's intriguing and suggestive Autobiologies (2015), which emphasises the extent to which the later nineteenth-century self became 'a biological subject' ${ }^{12}$ Even Harley, however, who gives considerable attention to Darwin's 'self narrativisation', omits any discussion of the importance of Darwin's understanding of the scientific mind in the framing of his 1876 'Recollections of the development of mind and character'. The resultant rare gap in the overpopulated field of Darwin studies would, in itself, provide a sufficient justification for taking Darwin as our case study. More importantly, as Feist appreciated, Darwin bequeathed us a document rich in self-analysis that historians are yet to exploit fully. We should not be misled by Darwin's claim that he undertook his autobiography in the expectation that it 'would amuse [him]'. Darwin's greatest intellectual breakthrough, after all, was the result of reading Malthus 'for amusement', and writing the 'Recollections' was no frivolous undertaking. ${ }^{13}$ Autobiographies were, as Charlotte Sleigh has emphasised, a key element in the process of scientist's self-fashioning; an exploration of Darwin's understanding of the psychology of his own scientific mind will throw light upon the thinker and his thought. ${ }^{14}$

\section{Darwin on Darwin's Mind}

Towards the end of May 1876, Darwin began the task of analyzing his own 'frame of mind' and delineating 'the mental qualities and conditions' upon which his achievements in science rested. Writing for 'nearly an hour most afternoons' for the next nine weeks, Darwin drafted a c.35,000 word manuscript, under the title 'Recollections of the development of my mind and character', an edited version of which was first published posthumously in $1887 .{ }^{15}$ Although often presented as an 'autobiography', Darwin's attempt to provide 'some sketch' of his life and 
collate family anecdotes was, as his own chosen title indicates, secondary to his ambition to analyse his own mental character and development. ${ }^{16}$ The 'Recollections', that is, were primarily an exercise in metacognition, in which Darwin set out to think about his own thinking, and about the cognitive conditions of scientific success. This led him to identify the attributes that constituted his scientific mind, and the course of its development. Three years later, in his The Life of Erasmus Darwin (1879), he returned to the topic and explored the scientific mind of his paternal grandfather. ${ }^{17}$ At no point in either text did Darwin attempt an explicit definition, yet in both he identified the chief characteristics of a scientific mind, made clear his view that these characteristics were innate and hereditary, and passed judgement on those whom he considered possessed - or did not possess - minds that were scientific. That this has elicited so little discussion in the multitudinous outputs of the 'Darwin industry' is, in part, a consequence of the location of Darwin's ideas. The 'Recollections' and Life of Erasmus are too often misread as end-of-life whimsy or of Darwin 'relaxing into autobiographical and familial mode', when they are better understood as integral parts of the overall intellectual project he began in the late 1830 s, and to which he dedicated his adult life. ${ }^{18}$

Darwin's autobiographical writings and his natural science are 'not separate or antithetical but mutually constitutive endeavours that nourish and interpenetrate one another'. ${ }^{19}$ Darwin straddled both the end of older natural history tradition, in which it was common to work from the individual and particular to the general, and a newer trend in which scientists interested in the human mind - including anthropologists, sociologists, ethnologists, psychologists, psychiatrists and eugenicists - made use of autobiographies for raw data. ${ }^{20} \mathrm{He}$ wrote the 'Recollections' and his Life of Erasmus at a time when the history of science was largely biographical, and autobiography was 'a suitable tool' with which to reflect on the nature of science, and when it was fashionable for scientists to furnish their life stories as case studies for 
their contemporaries. ${ }^{21}$ Twelve years earlier, for example, Charles Babbage had warned readers of his Passages from the Life of a Philosopher (1864) not to expect a conventional autobiography but rather the exploration of 'a variety of isolated circumstances' which illustrated human character; in his conclusion he gave explicit consideration to the mental training and to the 'peculiarities of mind [which] enabled [him] to accomplish what even the most instructed in their own sciences deemed impossible'. ${ }^{22}$ Babbage was also typical in his insistence that the Passages was complementary to, and ought to be read alongside, his scientific works. Perhaps the most famous and influential example of this, with which Darwin was certainly familiar, was John Stuart Mill's Autobiography (1873), published less than three years before Darwin wrote his 'Recollections' and self-consciously conceived as a companion to his other writings. ${ }^{23}$ Herbert Spencer averred the same rationale for his autobiography: 'it seemed to me that a natural history of myself would be a useful accompaniment to the books which it has been the chief occupation of my life to write'. ${ }^{24}$

In Darwin's case, the 'Recollections' assumed knowledge of his other writings and culminated in an overview of the main publications that had constituted Darwin's life. This was followed by self-analytical mini-essay of around 750 words, probably the result of Darwin's final afternoon of writing the first draft on 3 August 1876, which summed up the character of the mind of the author. ${ }^{25}$ In providing a distillation of the argument he had developed throughout the manuscript, Darwin borrowed the structure of chapter summaries and concluding sections of which he often made use in his zoological and botanical writings. The mini-essay rehearsed his failings - a memory that was 'extensive, yet hazy', an inability 'to follow a long and purely abstract train of thought', and 'no great quickness of apprehension or wit' - before turning to 'the favourable side of the balance', those qualities in which he considered himself 'superior to the common run of men'. These were: independence and hard work; openness and flexibility of 
mind; and the motivational qualities of drive and ambition. Although he claimed to have 'never turned one inch out of my course to gain fame', Darwin admitted that an 'ambition to be esteemed by my fellow naturalists' had accompanied his desire, evident from 'early youth', 'to understand or explain whatever I observed, - that is, to group all facts under some general laws'. In addition to these specific qualities, Darwin identified his 'love of science', which he described as 'steady and ardent', as 'the most important' of the 'complex diversified mental qualities and conditions' of his success. ${ }^{26}$

The opening paragraph of the 'Recollections' announced Darwin's intention to write as 'a dead man in another world looking back at my own life' ${ }^{27}$ This set the tone for the sparse and broadly chronological psychological self-analysis that followed, in which Darwin charted his earliest childhood memories and family relations; his boyhood behaviour, interests, and passions; and the limited impact of his formal education; but eschewed consideration of, for example, the emotional impact of his marriage or of fatherhood. For some later critics, this 'dead man' approach created serious shortcomings of both style and content, and produced 'a desultory assortment of anecdotes much more than the masterful marshalling of great moments in the life of a great man that might be expected' ${ }^{28}$ George Levine, in particular, made much of Darwin's extraordinary phrase and argued that the 'Recollections' was an autobiographical act of 'effacement', akin to the pursuit of mechanical objectivity in his wider work, in which the 'self is denied by the purgation from it of everything that is contingent, temporal, social, inherited, human' ${ }^{29}$ For Darwin's admirers, by contrast, the meticulously measured manner in which Darwin expressed himself in the 'Recollections' is a monument to his modesty. ${ }^{30}$ Both critics and admirers here miss the point. 
While Levine was undoubtedly correct to link the style and structure of the 'Recollections' to Darwin's science, the very act of a scientist's writing an autobiography constituted, as Sleigh has noted, an implicit 'rejection' of the self-abnegation demanded by mechanical objectivity. ${ }^{31}$ The 'Recollections' is built around Darwin's first person, subjective judgements, although his scientific understanding makes him wary of his own conclusions. As revealing as the 'dead man' quote is Darwin's comment towards the end of the 'Recollections' when, having announced his intention to 'try to analyse' his mental qualities, he immediately conceded, 'I am aware that no man can do this correctly'. ${ }^{32}$ Darwin was painfully aware that his judgements could be wrong, and this is why he peppered the 'Recollections' with phrases such as 'as far as I can judge', 'as far as I can see', and 'as far as I remember'. Rather than modesty, or sympathy with a broader mid-Victorian concern with honesty in autobiography, this textual tic expressed the compound of Darwin's doubts about the introspective method and the reliability of the brain as an evolved organ. ${ }^{33}$

Darwin shared in the prevailing objection to introspective judgements, expressed most clearly in Auguste Comte's dictum: 'The thinking individual cannot cut itself in two - one of the parts reasoning, while the other is looking on' ${ }^{34}$ This Comtean concern was almost certainly refreshed and reinforced for Darwin in the years preceding the writing of the 'Recollections' by his reading of Henry Maudsley, who cautioned the need 'to guard against the common metaphysical conception of mind, by recognising the true subjective character of the conception'. ${ }^{35}$ Darwin shared Maudsley's concern and did not go the whole way with Comte in regarding the psychological method as 'entirely worthless' ${ }^{36}$ His position was essentially that later adopted by G. H. Lewes, that 'while limiting the claims of introspection, we need not deny their validity'. ${ }^{37}$ Allied to Darwin's doubts about the introspective method, and further tempering his judgements in the 'Recollections', was Darwin's distrust of the reliability of any 
human mind, as an evolutionary product, to fully grasp its own situation. In his '1844 Sketch', Darwin had identified the mind's limitations as an obstacle to the acceptance of evolutionary theory. ${ }^{38}$ In the 'Recollections' he found the human mind equally untrustworthy on the question of religion when, having noted his own weakening theism, he commented: 'But then arises the doubt - can the mind of man, which has, as I fully believe, been developed from a mind as low as that possessed by the lowest animal, be trusted when it draws such grand conclusions?'39 The tentative tone of the 'Recollections' expressed neither purgation nor humility so much as the seriousness of its scientific task. ${ }^{40}$

Although Linda Peterson judged the 'Recollections' to be no more than a partial foreshadowing of more 'serious attempts', by Darwin's successors to write scientific autobiography, this underestimates the extent to which Darwin consciously plotted a parallel between the 'growth of the human mind viewed as a whole' and the development of his own individual mental organisation. This was another Comtean inheritance refreshed and reinforced in the 1860 s and 1870s, this time in the work of Ernst Haeckel and John Lubbock, and implicit in Darwin's account of his own mental development is a recapitulation of the evolutionary growth of the human mind. ${ }^{41}$ Thus Darwin traces his childhood as an ascent from a 'savage' state of theft, lying, and cruelty, to the morally upstanding humanity of the civilized scientist. ${ }^{42}$

Looking backwards, I can now perceive how my love for science gradually preponderated over every other taste. During the first two years my old passion for shooting survived in nearly full force, and I shot myself all the birds and animals for my collection; but gradually I gave up my gun more and more, and finally altogether to my servant, as shooting interfered with my work, more especially with making out the geological structure of a country. I discovered, though unconsciously and insensibly, that the pleasure of observing and reasoning was a much higher one than that of skill 
and sport. The primeval instincts of the barbarian slowly yielded to the acquired tastes of the civilized man. ${ }^{43}$

The presumed parallel between human ascent to civilisation and the preponderance of Darwin's 'love of science' is unmistakeable. His trajectory was gradual - Darwin used the word 'gradually' more than ten times in the 'Recollections' - and mirrored the evolutionary history of the human mind. For just as Darwin understood his own mind developing to become steadily more scientific, so too did he think that this was the path for the species in general. This point is easily missed. In almost all of his writings on humans Darwin's primary focus was upon demonstrating continuity with non-human animals, by identifying the rudiments of human mentality in animals and the remnants of animality in humans. ${ }^{44}$ But at one point in the Descent of Man (1871) Darwin permitted himself a brief look up at the higher mental development of humans, and found 'a perfect gradation from the mind of an utter idiot, lower than that of the lowest animal, to the mind of a Newton'. ${ }^{45}$ In the Descent, that is, Darwin made 'the mind of a Newton', a scientific mind, the highest human attainment; while in the 'Recollections', he charted his own mental development towards a scientific mind, humanity's highest evolutionary point. This ought to be borne in mind every time the 'Recollections' is praised or criticized for its author's supposed modesty. 


\section{Innate taste and education}

Darwin's sense that he was predestined for science was longstanding: in an autobiographical fragment written in August 1838 he had declared: 'I was born a naturalist' ${ }^{46}$ Thirty-eight years later, in the 'Recollections', he explained his scientific mind through the development of what he saw as his 'clearly innate' 'taste for natural history'. This assumption of 'innateness' shaped Darwin's account of his life. Events and encounters which, viewed differently, might have been rendered revelatory epiphanies - such as Robert Grant explaining Lamarckism or Darwin's first reading of Herschel - were acknowledged only insofar as they stimulated or awakened a natural 'passion' or 'stirred up ... a burning zeal to add even the most humble contribution to the noble structure of Natural Science'. His scientific habits, such as his love of collecting, Darwin stressed, predated his formal education, and the impact of that education was dismissed almost casually: school was underwhelming, university lectures 'intolerably dull'. ${ }^{47}$ This reflected something deeper than Darwin's own individual experience. Politically, it represented a polemical identification with the attack of T. H. Huxley and other scientists upon the dominance of classical learning in formal education; philosophically, it expressed Darwin's rejection of Lockean and Hartleyean sensationalist psychology, which led him to conclude that 'education and environment produce only a small effect on the mind, and that most of our qualities are innate' ${ }^{48}$ Not that Darwin was completely insensitive to the argument that non-psychological factors had contributed to his success. He was, for example, aware that economic wealth had given him 'ample leisure from not having to earn my own bread', and he was paradoxically grateful for the ill health that had saved him from 'the distractions of society and amusement' ${ }^{49}$ Such factors, however, were significant only to the extent that they had allowed Darwin to indulge his 'love of science - unbounded patience in long reflecting over any subject - industry in observing and collecting facts' and it was these innate qualities, combined with 'a fair share of invention as well as of common-sense', which, Darwin judged, constituted his scientific mind..$^{50}$ 
Even innate ability and predisposition, however, required development; and development, in turn, required time, training, and habit. This is an important point to which we will return; for the moment we only need to note that again, Darwin seems to have been drawing upon Maudsley, who presented the brain as an organ that could be developed, strengthened, or weakened. Whereas other internal organs, such as the liver and the heart, were capable from birth of full functionality, the brain 'matured by insensible degrees in the course of life'. It was 'born equal' only to its basic organic function; 'its highest development' took time, with both the brain and human intelligence following 'the same gradual progress from the general to the special' ${ }^{51}$ This, said Maudsley, was particularly important for those working in science where 'the scientific imagination by which hypotheses are successively framed until a true one is obtained, its verification completed, and a discovery thus made, is based upon a previous careful training of the senses in scientific observation, and works by means of sensory representations'. Taking up the cudgels against sensationalist psychology, Maudsley maintained that those with the greatest insights into nature saw beyond immediate sense impressions. An ordinary mind 'in describing scenery or events, will give a tedious picture characterised by minute industry and overwrought detail, in which there is no due subordination of parts, no organic unity of idea - in which truly soul is wanting - and from which, therefore, no one can carry away a true idea of the whole'. The 'truer man of science', according to Maudsley, was able to go beyond 'the cultivation of careful habits of observation' to achieve 'the co-operation of the sensory centres' in intellectual action. ${ }^{52}$ This higher stage required both innate ability and training.

Hence a motif of the 'Recollections' was the process by which, through time, training, and habit, Darwin's consistent 'love of science' - which explained both his initial passion and his commitment to improvement - had 'gradually preponderated over every other taste'. This phrase 'love of 
science' appears twice in the 'Recollections' - supplemented by one of 'love of natural science' and one 'love of natural history' - and can also be found in Darwin's correspondence. ${ }^{53}$ Darwin's use of it was neither unique nor original. The phrase was most closely associated with Alexander von Humboldt, who referred to a 'love of science' in his Personal Narrative and who was, in turn, praised by Babbage for having 'loved and pursued science for its own sake' ${ }^{54}$ Humboldt also seems to have introduced Darwin to the phrase, describing himself as acting 'avec toute la pureté de l'amour des sciences', in a letter to Darwin dated September 1839. ${ }^{55}$ Thereafter, Darwin would frequently praise correspondents variously for their 'love of science', their 'love for science', or their 'pure love of science'. ${ }^{56}$ On a psychological level, the phrase implied an enthusiasm that was all-consuming and, in Darwin's hands at least, an evolutionary progression. As we have seen, he described how, during the Beagle voyage, the "primeval instincts of the barbarian slowly yielded to the acquired tastes of the civilized man', and this process continued upon his return, reaching completion by the time he moved to Downe in 1842, at which point 'scientific work' became 'the chief enjoyment and sole employment' of his life. Thereafter his mind was exclusively scientific: 'a kind of machine for grinding general laws out of large collections of facts' ${ }^{57}$ Of course, at Down House Darwin was able to work without any obligations and the frequent use of the prefix 'pure' highlights the moral aspect of the 'love of science': it is an activity untainted by commercial or financial consideration. This was Humboldt's meaning in his letter to Darwin, and, in turn, Darwin's meaning when, in 1862, he praised the science writer W. B. Tegetmeier for his 'pure and disinterested love of science' ${ }^{58}$

In the 'Recollections', Darwin mainly defined the scientific mind in relation to his own positive attributes, including his 'love of science', but equally revealingly he also noted the absence of a scientific mind in others. The starkest contrast was with Thomas Carlyle, of whom he said: 'I never met a man with a mind so ill adapted for scientific research'. It was not simply that Carlyle 
'despised' all branches of science and held 'revolting' views about slavery; the real problem was that Carlyle's mind was 'very narrow', and his 'extraordinary power of drawing vivid pictures of things and men' was reckless as to accuracy and truth. ${ }^{59}$ This, of course, was at odds with the mental qualities of independence, openness, and observational skills which Darwin thought the hallmark of a science. Perhaps more illuminating, however, in helping us to understand Darwin's use of the term, was the contrast he drew with his own father, whose mind possessed some of the attributes of a scientist but who did not 'possess, as I think, a scientific mind' ${ }^{60}$

This striking, but rarely noticed, claim might be used as evidence of Darwin's Freudian rebellion against his father or, more interestingly, as Darwin anticipating, in his own way, the supposedly new autobiographical form that would be created by Edmund Gosse's Father and Son (1907): 'a memoir in which writers seek self-definition by contrasting their own life with their father's' ${ }^{61}$ But even if we restrict our interest more narrowly to Darwin's definition of a scientific mind, it is a remarkable remark. Robert Darwin, after all, was a distinguished doctor, an elected fellow of the Royal Society, and, on Darwin's account, an 'acute observer'. What made his mind, 'not scientific', according to his son, was that 'he did not try to generalize his knowledge under general laws' ${ }^{62}$ This was the same distinction that Maudsley made in his Physiology and Pathology, between a man who 'records, with a praiseworthy but tedious industry, the unconnected impressions made upon his senses, and never gets further than that', and the 'truer man of science' who combines 'by means of the organizing power of idea, the scattered impressions made upon the senses, [and] is able by comparison to complement or correct the impression made on a particular sense' ${ }^{63}$

Whence Darwin's innate talent came was not addressed directly in the 'Recollections' ${ }^{64}$ In noting that some of his own sons 'also exhibited an apparently innate taste for science', Darwin implied hereditary transmission, but he also explicitly discounted any debt to his own father: 'I do not think 
that I gained much from him intellectually'. ${ }^{65}$ In his Life of Erasmus, Darwin identified his paternal grandfather as the probable source of his own innate 'desire to collect objects of natural history, and feted Erasmus for possessing 'the true spirit of a philosopher', an 'incessant activity' of mind', and a 'vividness' of imagination which 'led to his great originality of thought, his prophetic spirit both in science and in the mechanical arts, and to his overpowering tendency to theorise and generalise'. For evidence of these traits, Darwin cited a letter from a friend, written in the wake of Erasmus's death, which delineated traits very similar to those Darwin had identified in himself in the 'Recollections', including: independence of character, 'uncommon activity of mind and facility of exertion', and quick perception of the 'analogies on which a new theory could be founded'. ${ }^{66} \mathrm{He}$ also considered the extent to which Erasmus had 'transmitted his characteristic qualities to his children'; concluding that Erasmus's eldest son, also called Charles, had 'inherited from his father a strong taste for various branches of science', but that Erasmus's second son Robert, Darwin's own father, had not inherited 'any aptitude for poetry or mechanics'. ${ }^{67}$ The clear implication was that the hereditary root of Darwin's own innate scientific ability was an example of the broader hereditary phenomenon in which grandchildren manifested the attributes of grandparents, despite their absence of similar attributes in the intervening generation. This was a subject Darwin discussed in his books Variation in Animals and Plants under Domestication (1868) and in The Expression of the Emotions in Men and Animals (1872), but which he had first broached at the start of his career in the 'mental rioting' of his post-Beagle notebooks. ${ }^{68}$

\section{Early interest}

As with so many other aspects of his thought, the foundations of Darwin's view of the scientific mind were laid in that extraordinarily rich period of the late 1830 s when he first formulated his theory of evolution by natural selection. ${ }^{69}$ As early as February 1838, in Notebook B, Darwin identified 'mind heredity' as part of his programme for exploration. ${ }^{70}$ The 'Metaphysics 
Notebooks' (M and N), moreover, which Darwin filled out in parallel with 'Transmutation

Notebooks' (D and E), were almost entirely concerned with the evolution of man and his mental faculties..$^{71}$ The importance of human psychology to the early development of Darwin's theory is easily overlooked, not least because of the suggestion in the Origin that psychology was a field for future studies. ${ }^{72}$ Yet the evidence of his notebooks is that for a short but highly significant period, between opening Notebook M in July 1838 and reading Malthus in October 1838, Darwin's thinking was dominated by questions of human psychology. ${ }^{73}$ This early interest, moreover, was every bit as personal and familial as the later 'Recollections' and Life of Erasmus, and prefigured those publications in some important respects.

In August 1838, aged only 29, Darwin sketched the beginnings of his first autobiography. This was an attempt to catalogue his earliest recollections as a means to understand his memory and how it related to his self-perception, and was almost certainly prompted by his father's remark, recorded in Notebook M, that 'people of weak minds, below par in intellect have very bad memories for things which happened in early infancy'. ${ }^{74} \mathrm{He}$ recalled that remark again almost forty years later in the second paragraph of the 'Recollections' ${ }^{75}$ Indeed, drawing upon insights from his father is a common feature of both the Notebooks and Darwin's more mature writings. Notebook M opened with the words 'My father', concluded with the same phrase, and used it twenty-two times inbetween. The very first entry set the tone: 'My father has seen innumerable cases of people taking after their parents, when the latter died long before, that it is extremely improbable that they should have imitated' ${ }^{76} \mathrm{~A}$ few pages in and Darwin was considering inheritance within his own family: 'My father says, perfect deformity, as an extra number of fingers.- hare lip or imperfect roof to the mouth stammering in my Father family (as in Lord Berwick’s family) are hereditary'. ${ }^{77}$ 
Thereafter, Darwin became particularly interested in the hereditary connection between grandfathers and grandsons, and explored inheritance primarily in terms of 'grandfathers'. First, he became fascinated by the possibility of reversion, and the final entry in Notebook M posed a question: 'Has my Father ever known disease in grandchild, when father has not had it but where grandfather was the cause by his intemperance'. ${ }^{78}$ Second, he began to use the term 'grandfather' as shorthand for all evolutionary ancestors. In early December 1838 , for example, the first of the three principles he formulated that would, he said, 'account for all' was that 'Grandchildren like grandfathers'. ${ }^{79}$ By this he meant both the literal resemblance across two generations - for which he asked his father for examples- and a more general evolutionary inheritance. Thus he summed up his evolutionary explanation of man's 'evil passions' as 'The Devil under form of Baboon is our grandfather!' ${ }^{\prime 80}$ Third, and stimulating his interest, was Darwin's growing conviction of his own inheritance from Erasmus. Thus he took the similarity of his and his grandfather's handwriting as symbolic: 'Handwriting is determined by most complicated circumstances as shown by difficulty in forging, yet handwriting said to be hereditary, shows well what minute details of structure are hereditary'. ${ }^{81}$

The relationship between grandfathers and grandchildren was similarly prominent in Darwin's work thirty years later in the Variation, when he outlined his pangenesis hypothesis. ${ }^{82}$ Examples of human psychology, mental illness, and inheritance furnished by his father again featured heavily, as did a concern with reversion. There was, Darwin noted, a 'great principle of inheritance', long recognised by agriculturists and expressed in a variety of languages, by which offspring resemble an ancestor more closely than either of their immediate parents, and a grandparent more than either parent. ${ }^{83}$ Darwin made the same point in the Expression, in the case of an English girl who, despite never meeting her French grandfather, resembled him 'to an almost absurd degree' and developed a Gallic shrug at only eighteen months of age. ${ }^{84}$ Beneath the continuity between the Notebooks and the 
Variation and Expression, however, Darwin had modified his understanding of reversion. In March 1863, he told Joseph Hooker that he had spent the past fortnight writing about reversions and gathered a 'curious collection of facts \& experiments', which 'have led me to view the whole case rather differently i.e. that the child never inherits from its grandfather or more distant ancestor, but that a crowd of characters lie latent in every living creature \& parent. ${ }^{85}$ Hooker asked for clarification: 'I do not understand you in saying that the child inherits nothing from its Grandparents except you mean (what I think you imply) that the Gndparents' properties, if developed by the grdchild, were latent in the parent—\& which I entirely believe'. ${ }^{86}$ Darwin was happy to agree that this was precisely what he meant. ${ }^{87}$

This refinement notwithstanding, there is a remarkable similarity between Darwin's treatment of the topic in his later writings and that in Notebook M. This is particularly true of the examples of human inheritance he cites in the Variation, some of which were even prefaced with the phrase 'my father' - which appears nine times across the Variation - and his revisiting of the question of the inheritance of handwriting. ${ }^{88}$ The Variation, that is, marked a return, thirty years on, to the question of human psychology and psychological inheritance. This interest then gathered pace with the publication of the Descent of Man (1871) and The Expression (1872). Indeed, in outline the content of these two books broadly mirrors that of Notebooks M and N. ${ }^{89}$ The apparent late flowering of Darwin's interest in the human mind and inheritance is, therefore, more accurately seen as a rediscovery of his earlier interests, with little new added. ${ }^{90}$ Although he had avoided direct discussion of humans in the Origin on the grounds that it would 'have been useless and injurious to the success of the book to have paraded without giving any evidence my conviction', when he did finally publish on humans it was without having undertaken any research comparable to the eightyear immersion in Cirripedia which preceded the Origin. ${ }^{91}$ 
But why, we might ask, did Darwin discontinue his psychological interests in the late-1830s, only to choose to return to them over thirty years later?

The first part of this question can be answered fairly easily: the key to the initial abeyance was Darwin's October 1838 reading of Malthus. Darwin's interest in mental processes had been prompted by the fact that 'these seemed to be the most rapidly modified of all biological functions, and therefore the most useful for testing the "Lamarckian" idea of the inheritance of acquired characteristics'. ${ }^{92}$ At this point Darwin's position was essentially Lamarckian, and his focus was on man as a 'frontier instance' - 'an opportunity to study intelligence as a central feature of adaptive change, and to study it in that organism in which it was most prominent' - and, therefore, to argue (downwards) for psychological continuity 'from man to animals' ${ }^{93}$ Once he had read Malthus, however, Darwin had a mechanism for selection, which meant that actual instances of inheritance, including the vexed questions of human psychology, could be put to one side. ${ }^{94}$ Hence the exclusive focus, in the 1842 and 1844 sketches, and in the Origin, upon plants and animals. Darwin, as Gruber put it, "by choosing to remain a biologist, "failed" to become a systematic psychologist'. 95

Darwin's return to the topic of man - tentatively in Variation, unapologetically in Descent and Expression, and then most fully in the 'Recollections' and Life of Erasmus - has been explained in at least two different ways. Desmond and Moore, in their book Darwin's Sacred Cause, argue that Darwin was driven by a desire to clarify his opposition to polygenesis; while Harely explains the return to human psychology as rooted in a wish to foreground sympathy and to temper the excessive individualism of the Origin. ${ }^{96}$ Without disputing the partial truth of either interpretation, I would suggest that Darwin's return to his apparently abandoned interests, also owed much to the changing cultural and intellectual context of studies of the mind; certainly, it had relatively little to 
do with Darwin's own research. There were personal reasons behind the writing of both books - the news that he was going to become a grandfather prompted Darwin to start the 'Recollections', and the absence of a 'good biographer' motivated the Life of Erasmus - but it is also notable that direct enquiries from German publishers preceded both books, indicating an appetite for what Darwin was to write. ${ }^{97}$ Whereas there was no obvious interest in, or outlet for, Darwin's psychological studies in the 1830 s and 1840 s, the post-Origin orgy of attempts to apply evolution to humans meant that across the 1860 s and 1870 s a space in which to explore such ideas was increasingly carved out. ${ }^{98}$

At first Darwin considered simply incorporating 'all of his material on human evolution into a single chapter on "man" (the most domesticated animal) in his book Variation', but then delayed again until the Descent: 'when I found that many naturalists fully accepted the doctrine of the evolution of species, it seemed to me advisable to work up such notes as I possessed and to publish a special treatise on the origin of man' ${ }^{99}$ With that task complete he found other old notes to work up. One set became Darwin's 'A Biographical Sketch of An Infant' (1877), which was based on the study he had made of the early months of the life of his first son William in 1840. The inspiration for that particular study also had its roots in Notebook M where Darwin had made various remarks on the behaviour of the child of his brother-in-law, Hensleigh Wedgwood. ${ }^{100}$ But it took the foundation of Mind in 1876, and the magazine's translation of Hippolyte Taine's account of his own daughter's acquisition of language, in early 1877 , to prompt Darwin into print. ${ }^{101}$ Similarly with Darwin's writings on the scientific mind, the roots reached back to the late 1830 s but it took a change in environment for them to flower in the mid to late 1870 s. A key contributor to that changing environment was, of course, Darwin's half-cousin Francis Galton.

\section{Galton's Men of Science}


It is impossible to write about the scientific mind without reference to Galton. As Feist noted, Galton's English Men of Science: Their Nature and Nurture (1874) was the seminal study. ${ }^{102}$ The book grew out of Galton's earlier work on 'hereditary genius' and his critical review of Alphonse de Candolle's Histoire des sciences et des savants depuis deux siècles (1873). ${ }^{103}$ Whereas de Candolle explained the success of Geneva's men of science by a combination of historical and sociological factors, Galton offered 'a Natural History of the English Men of Science of the present day', which emphasized the biological and hereditarian basis of the scientific mind. ${ }^{104}$ His research method was a seven-page questionnaire sent to around 180 leading 'men of science' seeking information on four main areas: 'their earliest antecedents, including hereditary influences'; 'the inborn quality of their mind and body'; the 'causes that first induced them to pursue science'; and 'the education they received and their opinions on its merits'. ${ }^{105}$ The recipients were selected from elected Fellows of the Royal Society, plus one or two associated clubs. On the basis of responses from about half of those surveyed, Galton delineated a psychology of science, in which a hereditarily rooted behavioural consistency was key. ${ }^{106}$ Galton did not attempt a strict definition of a 'man of science'on the good Darwinian grounds that natural groups 'have nuclei but no outlines; they blend of every side' - but argued that they were distinguished not only by the fact that they loved science, but that they loved her consistently. ${ }^{107}$ Whereas a 'normal' pattern was for a man's tastes to change across his lifetime - from 'inquiry in childhood', to 'fierce passions in youth', and then 'ambitions of more mature life' - 'a special taste for science seems to be so ingrained in the constitution of scientific men, that it asserts itself throughout their whole existence'. ${ }^{108}$ Thus, in a comforting confirmation of what he had set out to prove, Galton's data demonstrated that 'scientific tastes appear to have been innate'. 109

As we have seen, this is very similar to the language Darwin deployed in the 'Recollections', and it would be easy to assume that Galton was a significant influence. Darwin, after all, wrote the 
'Recollections' three years after receiving Galton's questionnaire and two years after reading Men of Science, and was a guarded admirer of aspects of Galton's work, referring favourably to his halfcousin in both the 'Recollections' and the Life of Erasmus. ${ }^{110}$ Galton, for his part, identified a hereditary propensity towards 'a love of natural history and theory, and of an aptitude for collecting facts in business-like but peculiar ways' in the Darwin family, and declared that Darwin's Origin had marked an 'epoch in my own mental development'. ${ }^{111}$ Yet as obvious as this connection is, to conclude that Darwin followed Galton's lead would be wrong. Not only did Darwin's interest in his own mental development predate Galton's work, but also the two men had significant methodological and ideological differences in their approach to the study of the scientific mind.

Methodologically, Galton championed an introspective approach with which Darwin, as we saw above, had little sympathy, and was possessed by an overwhelming desire to quantify 'genius' ${ }^{112}$ In the covering letter accompanying his questionnaire, Galton argued that 'none are more likely to appreciate the inquiry or to give correct information than Men of Science', and in the resultant book declared that their returns bore 'all the marks of a cool and careful self-analysis'. ${ }^{113}$ Darwin, however, pointedly passed his copy of the questionnaire to his son George to fill out on his behalf, on the grounds that it is 'impossible for any one to judge about his own character'. ${ }^{114}$ Darwin was probably more sympathetic to the criticism of one reviewer, Francis Lloyd, who complained that in citing 'the confessions of a few individuals as a basis for exact conclusions', Galton erred 'as wildly as those of the ancient Greeks who accepted oral traditions and travellers' stories as objective truth'. ${ }^{115}$ Galton, however, had wanted to go even further. In his Royal Institution lecture of February 1874 , he had argued that his questionnaires would enable him to undertake a quantitative analysis, by having his respondents estimate their abilities by 'degrees', in line with the table of 'Natural Gifts' he had developed in Hereditary Genius. ${ }^{116}$ By the time he published, Galton had abandoned the idea in favour of a less precise language of words such as 'large' and 
'considerable'. ${ }^{117}$ Darwin, it seems, was not alone in telling Galton: 'I find it quite impossible to estimate my character by your degrees'. ${ }^{118}$

Ideologically, Darwin and Galton were separated by the gulf between the former's optimistic liberalism and the latter's pessimistic conservatism. ${ }^{119}$ As in all his writings, Galton's Hereditary Genius and English Men of Science were both underpinned by fear of a future in which all forms of genius, including the scientific mind, were under threat from a differential decline in the birth rate. He argued that the marriages of the parents of the scientific men on his list 'tended to produce differentation and purity of race', but worried that men of science had fewer children and that this created a clear 'tendency to an extinction of the families of men who work hard with the brain'. ${ }^{120}$ At times, Darwin too expressed concern about a differential decline in the birth rate, but ultimately he harboured fewer worries that men of genius would not produce progeny (perhaps as a result of his own fabulous fecundity, compared with Galton's childless marriage). ${ }^{121}$ More generally, in the Descent Darwin repeatedly distanced himself from Galton's pessimism by looking confidently towards an evolutionary future in which 'virtuous habits will grow stronger, becoming perhaps fixed by inheritance' and 'the struggle between our higher and lower impulses will be less severe, and virtue will be triumphant'. ${ }^{122}$ In Darwin's optimistic view, the triumph of the scientific mind was part of this more assured general progression.

The most important difference between Darwin and Galton in their understanding of the scientific mind, however, came in their relative appreciation of the importance of hard work. Francis Darwin's editing of the 'Recollections' exaggerated the image of his father as a 'self-made man of the nineteenth century' whose 'life exemplified effort, achievement, and personal virtue in the face of difficulty', but Darwin himself had laid the basis for this presentation. ${ }^{123}$ Even after declaring that he was inclined 'to agree with Galton in believing that education and environment produce only 
a small effect on the mind of any one, and that most of our qualities are innate', Darwin emphasized the importance of hard work. ${ }^{124}$ Writing to Galton, after having read the first fifty pages of Hereditary Genius in 1869, Darwin seemed to be seeking a middle way: 'You have made a convert of an opponent in one sense, for I have always maintained that, excepting fools, men did not differ much in intellect, only in zeal and hard work; and I still think this is an eminently important difference'. ${ }^{125}$

Thus a recurring refrain of the 'Recollections' is how hard and how 'steadily' Darwin had worked. This was consistent with his admiration for Samuel Smiles's biographies, which he always read, he told their author, with 'extreme pleasure'. ${ }^{126}$ Whatever else he took from these books, Darwin undoubtedly imbibed a sense of work as an inherent moral good; thus in the 'Recollections', he noted that whenever he discovered himself to have 'blundered' or to have been unfairly praised or criticized, "it has been my greatest comfort to say hundreds of times to myself that "I have worked as hard and as well as I could, and no man can do more than this." The highest praise Darwin could find for his close friend Joseph Hooker was that he was 'the most untirable worker that I have ever seen'. ${ }^{127}$ Harley maintained that Darwin's emphasis on hard work pushed him away from 'recognisably "Darwinian" accounts of how character is caused' and towards a Protestant tradition of personal responsibility and liberal individualism, but this dichotomy is too stark. ${ }^{128}$ As we have seen, Darwin regards the characteristics of such a mind as innate, but there realisation was not inevitable. In choosing the noun 'development' to describe the process at work in the 'Recollections' - these were 'Recollections of the Development of my Mind and Character'Darwin was able to emphasise both an embryological unrolling (the prevailing biological understanding of the word) and an active willing, realised through training. The 'work' that he lauded was not work for work's sake, but the scientific practice of experiment. 
For Darwin, the scientific mind was pre-eminently an experimental mind, and because experiments entailed 'work' they represented a point of elision between morality and methodology. This was another divergence from Galton, who made only rare forays into experimentation and represented the start of a new mathematical and statistically-based approach to scientific inquiry. Darwin, by contrast, followed inductivist principles in stressing the importance of experimentalism to the scientific mind. ${ }^{129}$ Thus in his Life of Erasmus, Darwin noted that although his grandfather 'indulged largely in hypotheses', it was the fact that he 'knew full well the value of experiment' that showed that he possessed the 'true spirit of a philosopher'. He also quoted approvingly his grandfather's definition of a fool as 'a man who never tried an experiment in his life'. ${ }^{130}$ Darwin never called Herbert Spencer an outright fool, but time and again in their correspondence he and Hooker lamented Spencer's unwillingness to put in the hard graft of observation and experiment. ${ }^{131}$ In the 'Recollections' he characterized Spencer as possessing an 'extremely egotistical' mind that shied away from hard, experimental work: 'over and over again', Darwin complained, 'I have said to myself, after reading one of his discussions, - "here would be a fine subject for half-a-dozen years' work."'. That some imagined Spencer's 'fundamental generalisations' comparable 'with Newton's laws!" was, for Darwin, absurd; the synthetic philosopher's 'deductive manner' was, Darwin said, 'wholly opposed to my frame of mind'. ${ }^{132}$

Indubitably Galton's questionnaire and his subsequent publications encouraged Darwin to think about the question of the scientific mind. Galton was, after all, one of the most important figures in the new intellectual firmament in which questions of mind, talent, and inheritance, and their interrelationships, came to be discussed, and it was within the space that Galton helped to create that Darwin revived his own earlier interests of the 1830s. Darwin, however, owed no specific debt to English Men of Science, and notably avoided adopting that 'convenient jingle of words', the 'nature/nurture' dichotomy, which was the book's enduring bequest to subsequent psychologists. ${ }^{133}$ 
The significance of the book for Darwin lay less in its specific arguments and more in the change of the tone it embodied. As Richard Yeo noted, Galton's unapologetic ability to single out 'men of science' was itself a 'mark of the consolidation which had taken place in the status of science during the nineteenth century'. Prior to Galton, metascientific discourse had been dominated by William Whewell's natural theology and framed by the fact that 'science was a relatively insecure cultural activity'. ${ }^{134}$ Whewell's focus had been on questions of morality, method, and the history of scientific discovery. Galton's was on inheritance and biological explanations. His half-cousin's work emboldened Darwin, but equally he never entirely escaped key aspects of the Whewellian perspective in which he had learned his trade and, as a result, Darwin's conception of the scientific mind encompassed a mid-century metascience concern with moral character alongside a more obviously Galtonian emphasis on hereditary.

Thus when Darwin identified Newton as the epitome of the scientific mind, he was praising more than a set of psychological predispositions or innate intellectual attributes. As Rebekah Higgitt has shown, in the early and mid-nineteenth century, Newton was rendered the exemplar of the morality and method of science by presenting him as a scientific 'artisan'. The inductivism for which Newton was lauded was both methodologically correct and morally sound, because it represented a hardworking, labour-intensive route to knowledge. ${ }^{135}$ The Newton of the nineteenth century, that is, was celebrated for slogging his way to scientific insight. This 'British' approach - which was often contrasted with the 'French' model of a mercurial savant - left little room for inspirational genius, and emphasised careful rather than quick minds, and perseverance and sustained reflection over memory and quick reflexes. These, of course, were precisely the attributes that Darwin selfidentified in the 'Recollections'. This was very different to Galton, whose emphasis on innate genius placed a much lower premium on hard work and made a much lower estimate of what could 
be achieved by diligence, application, and sheer slogging. Revealingly, English Men of Science made no mention of Newton.

\section{The scientific mind and the religious mind}

While Darwin shared aspects of Whewell's vision of the scientist as a moral exemplar of strict method and hard working habit, he parted company from his former friend on the question of religion and the scientific mind. ${ }^{136}$ For Whewell, a scientific mind and a religious mind were not only compatible, they were reinforcing elements in the overarching Divine Mind. In his Bridgewater Treatise - Astronomy and General Physics considered with reference to Natural Theology - he developed this point to argue that inductive habits of mind were of greater value than deductive, in both science and religion. ${ }^{137}$ In Whewell's view, nature and mind would always 'correspond' for the simple reason that both were 'the works of the same Maker' and that 'the constitution of the world is marked with the Thoughts of the Divine Mind, and the human mind is, in part, a sharer in the Thoughts of the Divine Mind'. ${ }^{138}$

One scientific autobiography, written two years before Darwin's 'Recollections', which accorded with this view, was Mary Somerville's Personal Recollections (1874). She, like Darwin, was hesitant but persistent in pursuing an introspective analysis of her own mental qualities - 'No analysis is so difficult as that of one's own mind, but I do not think I err much in saying that perseverance is a characteristic of mine'. However,unlike Darwin she found that 'the natural bent' of her mind reinforced, as Whewell argued it would, her religious belief.

Nothing has afforded me so convincing a proof of the unity of the Deity as these purely mental conceptions of numerical and mathematical science which have been by slow degrees vouchsafed to man, and are still granted in these latter times by the Differential 
Calculus and the Higher Algebra, all of which must have existed in that sublimely omniscient Mind from eternity. ${ }^{139}$

Darwin's account throughout his 'Recollections' was rather different. In particular, the section on 'Religious Belief' charts the contraction of his faith, as Scripture, Christianity, theism, and all 'chimerical hopes' of discovering final causes, were cast aside one by one, in parallel with the development of his scientific mind. ${ }^{140}$ As we have already noted, consciously or not, Comte's contention that 'each of us contemplating his own history' finds 'a theologian in childhood, a metaphysician in youth, and a natural philosopher in manhood' echoed through Darwin's text, and seems to underpin his account of a purging of his theological and metaphysical beliefs as he fully embraced natural selection. ${ }^{141}$

Darwin's debt was perhaps not as obvious as that of Harriet Martineau, who drew from Comte a 'comprehensive substitute' for the 'biblical typology' that usually gave coherence to autobiographical experiences, and divided her life, and structured her autobiography, into broadly equal theological, metaphysical, and positivistic stages. ${ }^{142}$ But implicit in Darwin's account of his own mental development is a recapitulation of the evolutionary growth of the human mind. Thus Darwin's highly selective choice of childhood anecdotes emphasizes those 'savage' or barbarian characteristics - lying, theft, and wanton cruelty to a puppy - that eventually give way to the morally upstanding characteristics of the a scientist, as the adult Darwin attains a state of 'civilisation'. ${ }^{143} \mathrm{He}$ even reveals himself to be a child theologian in attributing his lightning speed, in running back and forth between home and school, to the prayers he offered to God. ${ }^{144}$ Whether or not this came directly from the parallel Comte drew between an individual mental organisation and the 'growth of the human mind viewed as a whole' matters less than its meaning, and the implication was clear: contra Whewell, pro Comte, Darwin saw his scientific mind and the 
religious belief in an inverse relationship. For Darwin, the scientific mind could not be a religious mind, and the more scientific a mind became the less religious it was.

On balance, it seems reasonable to conclude that Comte influenced Darwin's thinking on the scientific mind, and certainly there were good reasons why he might have been reticent about acknowledging this debt. Comte - or at least the version of Comte that Darwin derived indirectly from David Brewster's article in the Edinburgh Review - was prominent in the M and N Notebooks where, as we have seen, Darwin first formulated his understanding of the scientific mind. ${ }^{145}$ Reading Brewster at the Athenaeum in August 1838 had been momentous enough to give Darwin a headache, which he cured with a dose of Dickens, and to lead him to send an excited letter to Lyell, declaring the review 'capital'. ${ }^{146}$ More specifically, Darwin was impressed with the three-stage theory of development, and made use of it on a number of occasions throughout his life, even though Whewell had rejected it as unscientific. ${ }^{147}$ Thus the criticism Darwin made in Notebook N that 'Zoology itself is now purely theological', was echoed in an 1861 letter to Lyell in which Darwin complained that the response of Asa Gray and Herschel to the Origin 'merely show that the subject in their minds is in Comte's theological stage of science'. ${ }^{148}$

Herschel was one reason why Darwin might have been reluctant to acknowledge any debt to Comte. The force of Herschel's attack on Comte in his 1845 Presidential Address to the British Association for the Advancement of Science, coming on top of Whewell's acerbic assault in his introduction to his Philosophy of the Inductive Sciences (1840), meant, as Schweber put it, that any avowal of debt would have been 'one more cross' for Darwin to bear. ${ }^{149}$ Indeed, even without such an avowal, by the mid-1860s Comte was being used as a stick with which to beat Darwin - as well as Mill and Spencer - and it was, in part, to protect evolutionary science from becoming too tarred with a Comtean brush, that Huxley launched a preemptive attack in an eviscerating piece for the 
Fortnightly Review. ${ }^{150}$ Darwin praised his friend's 'clever' article, and said that it had cured his 'vague wish to read Comte'. ${ }^{151}$ Three years later, however, he told another correspondent that he had read Harriet Martineau's The Positive Philosophy of Auguste Comte '\& some other books on Comte', and even in the immediate wake of Huxley's article he risked his tempestuous friend's ire by forwarding a critique of the Fortnightly Review on behalf of the 'red-hot Comtist', Vernon Lushington. ${ }^{152}$ This evidence of a Comtean connection is, of course, far from conclusive, but it is consistent with structure of the 'Recollections', and especially the section on 'Religious Belief', which leaves no place for religion in the scientific mind.

That is not to say that Darwin thought the scientific mind necessarily an atheistic mind. Darwin, of course, famously stopped short of declaring himself an atheist - 'I have never been an atheist in the sense of denying the existence of a God', as he put it in a letter of 1879 - and, in the 'Recollections' declared: 'The mystery of the beginning of all things is insoluble by us; and I for one must be content to remain an Agnostic'. ${ }^{153}$ It is important to be clear what Darwin is saying here, because his words might be over-interpreted by those eager to reconcile Darwinism and religion. Not denying the existence of a God and allowing that a mystery is 'insoluble', is not equivalent to seriously entertaining the proposition that there might be a God or that the solution to the 'mystery' might be a supernatural one. Rather than a theological statement of his openness to potential supernatural explanations, Darwin was asserting the methodological and psychological openness required of a scientific mind. Agnosticism for Huxley, who popularised - and almost certainly prompted Darwin's use of - the term, meant that 'a man shall not say he knows or believes that which he has no scientific grounds for professing to know or believe'. ${ }^{154}$ Given that such knowledge of the supernatural is never possible, the scientific mind was, by necessity, agnostic. But for Darwin, a scientific mind was not merely agnostic in the sense of being neutral: a scientific mind was an actively sceptical mind. 
This was a point Darwin made clear in two additions to the text of the 'Recollections' in 1879 , three years after he had first drafted it. In the original version of his mini-essay at the end of the 'Recollections' summarising the key features of his mind, Darwin had declared himself 'not very sceptical - a frame of mind which I believe to be injurious to the progress of science' ${ }^{155}$ His meaning here is not immediately obvious - he might mean either that scepticism is injurious to science or that a lack of scepticism is injurious to science - but any confusion was eliminated three years later by his insertion of an 850 -word addendum giving three examples, drawn from his own experience, of how 'a good deal of scepticism in a scientific man is advisable to avoid much loss of time'. ${ }^{156}$ The second of his two additions came at the end of the 'Religious Belief' section, where Darwin added a paragraph, which begins approvingly: 'Nothing is more remarkable than the spread of scepticism or rationalism during the latter half of my life'. ${ }^{157}$ The prompt, both for this comment and his clarification of the value of scepticism to scientific progress, would appear to be the rapidly changing intellectual context of the late 1870s. In particular, a furore had followed the publication of W. K. Clifford's 'The Ethics of Belief' in 1877, which had argued that belief had no place in science and that it was 'wrong always, everywhere, and for anyone, to believe anything upon insufficient evidence'. ${ }^{158}$

Scepticism in Darwin's formulation of the scientific mind had two overlapping meanings. On one level, it was a non-religious position: a sceptic was one who doubted established religious belief hence Darwin's elision of 'scepticism' and 'rationalism' in his addition to the 'Religious Belief' section of the 'Recollections'. On another level, it referred to a psychological tendency to question all ideas, even one's own. This was the type of scepticism Darwin had in mind when he reflected upon his own scientific work, and noted that 'with the exception of the Coral Reefs, I cannot remember a single first-formed hypothesis which had not after a time to be given up or greatly 
modified'. ${ }^{159}$ What we might call religious scepticism and methodological scepticism both drew upon what Clifford called the 'bounden duty of mankind' to question 'all that we believe' and never to accept any statement 'which is contrary to, or outside of, the uniformity of nature'. ${ }^{160}$ Scepticism, that is, was good scientific method. Modern usage of the term, particularly in relation to the science of climate change, can make scepticism appear an anti-scientific attribute, but for Darwin it was the default position of a scientific mind.

This did not mean universal doubt. Even Clifford warned against the 'universal sceptics'. Darwin's meaning is better captured by what Feist called 'open scepticism': a predisposition to question authority, but not taken so far as to doubt all knowledge, and in which scepticism is the default because of the susceptibility of the brain, as an evolved organ, to mislead itself. ${ }^{161}$ As with the other characteristics of the scientific mind, scepticism was an innate inherited trait capable of being enhanced by exercise and training: it had taken an act of will for Darwin to keep his 'mind free, so as to give up any hypothesis, however much beloved', but this was possible because: 'As far as I can judge, I am not apt to follow blindly the lead of other men'. ${ }^{162}$ Early in their marriage, his wife Emma had asked Darwin to apply a different standard to religious questions to those he used for science. ${ }^{163}$ We do not have Darwin's reply, but it seems doubtful that he could have agreed to do this, even if he had wanted to. For Darwin, the mark of a scientific mind was the demand for proof and evidence to precede belief, and the absence of such evidence ensured his rejection of religion. ${ }^{164}$

\section{Masculinity and aesthetic taste}

In his 1879 addition to the 'Religious Belief' section, Darwin commented that his father regarded 'scepticism or rationalism' as an almost exclusively male attribute, but that he had himself known 'several married ladies, who believe very little more than, their husbands'. ${ }^{165}$ This is noteworthy as 
the only occasion in the 'Recollections' where Darwin gives any hint at all that a key attribute of a scientific mind might be found in females as well as males. In almost every other respect the 'Recollections' was a heavily gendered text. Women were almost entirely absent from its pages, and the few mentions they receive emphasise a conventional feminine identity, and say little or nothing directly about the mind. Thus Darwin's mother - who died when he was eight years old - is dispensed with in two sentences that include reference to her 'black velvet gown, and her curiously constructed work-table', while his sisters, who played an important role in his upbringing, are described as 'kind and affectionate' and credited with teaching him 'humanity'. ${ }^{166}$ Darwin's wife Emma is also largely absent - even from the short chapter that covers the period of their courtship and is only ever referred to in her in roles as 'a good Mother' and her husband's 'greatest blessing'. She is lauded for her kindness, patience, and sympathy, and declared Darwin's 'superior in every single moral quality', as well as his 'wise adviser and cheerful comforter throughout life'. ${ }^{167}$ In part, of course, the 'Recollections' simply reflected the gendered conventions of Victorian autobiography in which women were routinely presented in the guise of an 'Angel in the House', but this presentation also tells us something about Darwin's understanding of the scientific mind: Emma's almost total absence from the 'Recollections' is perfectly consistent with Darwin's proclaimed objective of charting his 'mental development' because, as he saw it, Emma was not part of that development. ${ }^{168}$

Darwin reasoned out his gendered construction of the scientific mind in a very particular way. Whereas contemporaries such as Spencer and Maudsley attributed the mental differences they identified between male and female minds to 'a physiological necessity', rooted in the intellect restricting capacity of the female body as a 'closed energy system', Darwin eschewed an argument that may have sounded a little too Lamarckian, in favour of a distinction rooted in a more hardwired inheritance and the legacy of sexual and natural selection. ${ }^{169}$ The notorious section of the 
Descent, 'Difference in the Mental Powers of the two Sexes', in which Darwin discussed the differing mental characteristics of men and women, and included science as one of the subjects in which lists of the 'most eminent men and women ... would not bear comparison', made clear that the divergence was fundamentally a consequence of heredity. According to Darwin, the 'higher powers' of males, which ensured preeminence in science and other subjects, were honed through selection (natural and sexual), and confirmed by gender differentials in inheritance. ${ }^{170}$ In the Variation, he had allowed that this could be more complex than a direct father to son, or mother to daughter inheritance, discussing deferred inheritance across generations, in which peculiarities could sit 'latent in the opposite sex' and skip a generation, allowing a father to 'transmit through his daughter any character to his grandson; and the mother conversely to her granddaughter'. It was possible, that is, for a son to bear a greater resemblance to 'his maternal than his paternal grandsire in some male attribute', which 'the mother cannot possess or exhibit'. ${ }^{171}$ Thus the role of the female in transmitting the scientific mind was to incubate genius across a generation, and in his Life of Erasmus, Darwin noted that it was precisely by this matrilineal descent that Galton had inherited his own scientific mind from their shared grandfather. ${ }^{172}$

This was an insight Galton was more than ready to accept. In reviewing the questionnaires submitted for English Men of Science, Galton noted 'the relatively small encouragement received from the mother in developing an interest in science and was unable to identify any respondent who 'speaks of having inherited a love of science from his mother, though, of course, she may, and probably has, often transmitted it from a grand-parent'. ${ }^{173}$ Where Darwin and Galton parted company in their equally gendered readings of the scientific mind, was not on the question of patrilineal inheritance, but in their differing assessments of what constituted the masculinity of the scientific mind. For Galton, a scientific mind was a hyper-masculine mind: men of science were 'especially manly'; their character 'strongly anti-feminine'; and they had 'little sympathy with 
female ways of thought'. The 'special excellencies' of the female mind, including 'enthusiasm and love', were contrasted unfavourably with the 'colder attractions of science', which demanded 'calm judgment', and Galton was unapologetic, celebratory even, of the fact that the 'man of science is deficient in the purely emotional element'. ${ }^{174}$ In 'a few cases', among his questionnaire respondents, Galton noted that the scientific 'hunger for truth' was so ardent that it created 'a repugnance to works of avowed fiction'; this was, however, nothing to lament. ${ }^{175}$ Darwin's view was different. For Darwin, the 'higher powers' - honed in the evolutionary process - that distinguished the male were of 'imagination and reason'. ${ }^{176}$ It was not, it should be stressed, that Darwin thought there was anything to be gained from a feminine mind; it was rather that his understanding of the masculine mind was more nuanced. Unlike Galton, Darwin retained the Romantic concern of earlier nineteenth-century authors who feared the contrast of an emotionally impoverished man of science with the more rounded and fulfilled poet or artist. ${ }^{177}$

Rather than celebrating the limited interests and emotional deficiency of the scientific mind, Darwin regretted the 'curious and lamentable' loss of the 'higher aesthetic tastes', which had reduced him to 'a kind of machine' for grinding out scientific laws. ${ }^{178}$ For all of Darwin’s undoubted partisanship, he did not regard the scientific mind as the sole and exclusive form of genius. Thus, when in the Descent he sought to illustrate the distance 'between the highest men of the highest races and lowest savages', he chose 'a Newton or Shakespeare' to illustrate the gap. ${ }^{179}$ His regret was that in his own life he had failed to retain his enthusiasm for the latter. The 'intense delight' he had once taken in Shakespeare as a schoolboy had been replaced by a feeling that the bard was 'so intolerably dull that it nauseated me', and his 'exquisite delight' in music had vanished. Whereas once he had traversed the Pampas with a copy of Paradise Lost stuffed in his saddle bag, in middle-age he had become someone unable to 'endure to read a line of poetry'. His enjoyment of fiction was undiminished, but it was lowbrow novels, featuring 'a pretty woman' and a happy ending, read 
aloud to him by his wife or one of his daughters, from which he took pleasure. ${ }^{180}$ Darwin did not doubt that this cultural impoverishment and emotional sterility was a byproduct of his scientific work. But, far from regarding it as a necessary or desirable attribute of the scientific mind, Darwin maintained that a weekly regime of poetry reading and musical appreciation would have prevented his loss. It was an 'atrophy' contingent on his own weakness and the poor habits his pursuit of science had encouraged, rather than an inherent defect of a particular type of mind that led men of science to neglect literature. Indeed, not only could this be avoided, but it should be, because the loss of the higher tastes was 'injurious to the intellect, and more probably to the moral character, by enfeebling the emotional part of our nature' ${ }^{181}$

This reference to 'the emotional part of our nature' is a reminder of Darwin's enduring attachment to the Humboldtian strains of his youth that were being squeezed out of the self-fashioning of 'men of science', according to Ellis, by Galton's hyper-masculinity and the Carlylean heroism of Darwin's allies in the X-Club. ${ }^{182}$ As with his equally Janus-faced position between Whewell and Galton on the questions of method and morality versus biological inheritance, Darwin found himself straddling the terrain between an older metascientific tradition, rooted largely in natural theology, which he rejected, and a newer amoral, biological, and hereditary understanding, with which he was not entirely comfortable. Darwin's understanding of the scientific mind, that is, drew from older traditions, even as it anticipated the much harder hereditarian interpretations of Galton and future eugenicists. Ultimately, the success of the hereditarians in developing evolutionary theory left Darwin's own view of the scientific mind looking rather dated.

\section{Conclusion}

The conclusions to be drawn from the case study of any one individual are inevitably limited, even if that individual is Charles Darwin. But as well as casting new light upon some familiar ground in 
the study of Darwin, the aim of this article has been to make a broader point: the study of the scientific mind is a topic far too important to be left to non-historians. Darwin's view of the scientific mind, as outlined in his 'Recollections' and his Life of Erasmus Darwin, paralleled and complemented the progressionist anthropology of the Descent. His scientific mind, that is, was a white, western, male mind from which women and non-Europeans were excluded by the actions of natural and sexual selection across evolutionary history. Subsequent constructions, however much they differ from Darwin in detail, are always similarly culturally conditioned. In particular, almost a century and a half after the 'Recollections' it is still commonly assumed that a scientific mind is a male mind. Historians have a responsibility to help to break down such exclusionary prejudices by exploring their historical roots. Far from being an essential, ahistorical, psychological entity, the 'scientific mind' is always an agglomeration of historically specific prejudices and presumptions. My study of Darwin illustrates this and points to the need for a similarly historical approach to the question of the scientific mind today. 
David Stack, Department of History, University of Reading, Reading, RG6 6AA, U.K. Email:

d.a.stack@reading.ac.uk

\section{Acknowledgements}

I would like to thank the editor and my two anonymous referees for their comments on a previous draft of this article.

\section{ENDNOTES}


${ }^{1}$ J.W.N. Sullivan, 'The Scientific Mind' pp.115-127 in L. E. Saidla \& W. E. Gibbs, Science and the Scientific Mind, New York, 1930, p.115. This chapter was reprinted from Sullivan's own Aspects of Science, New York, 1925. See S. Shapin, The Scientific Life. A moral history of a late modern vocation, Chicago: Chicago University Press, 2008, especially chapters 2 and 3 .

2 'Editorial Notes', The Women's Signal, 20 Sept. 1894.

${ }^{3}$ For an early use of the term see The Lady's Monthly Museum, 1 December 1803

${ }^{4}$ https://books.google.com/ngrams/graph?content=scientific

+ mind\&year_start $=1800 \& y e a r \_e n d=2000 \&$ corpus $=15 \&$ smoothing $=3 \&$ share $=\&$ direct_url $=\mathrm{t} 1 \% 3 \mathrm{~B} \% 2 \mathrm{Cscientific}$ $\% 20$ mind $\% 3 \mathrm{~B} \% 2 \mathrm{Cc} 0$

5 J. E. Chaplin and D. M. McMahon, Genealogies of Genius, London: Palgrave Macmillan, 2016, p.1; J. E. Chaplin, The First Scientific American. Benjamin Franklin and the Pursuit of Genius, New York: Basic Books, 2006, p.2.

${ }^{6}$ G. J. Feist, The Psychology of Science and the origins of the scientific mind, Yale: Yale University Press, 2006, pp.3-4, p. 155 .

${ }^{7}$ The Darwinian paradigm is very appealing for those making deterministic claims, see, for example, Frank J. Sulloway, Born to Rebel: Birth Order, Family Dynamics, and Creative Lives, New York: Penguin Random House, 1996. Feist, Psychology of Science, p.15, p.80, p.84.

${ }^{8}$ The most important early studies of Victorian masculinity said very little about science, see for example, J. Tosh, $A$ Man's Place. Masculinity and the Middle-Class Home in Victorian England, Yale: Yale University Press, 1999 and J. Eli Adams, Dandies and Desert Saints: Styles of Victorian Masculinity, Cornell: Cornell University Press, 1995.

${ }^{9}$ R. Barton, “"Men of Science": Language, identity and professionalisation in the mid-Victorian scientific community', History of Science 41 (2003) pp.75-119; L. J. Daston and P. Galison, Objectivity, Cambridge: Mass., Zone Books, 2010; H. Ellis, Masculinity and Science in Britain, 1831-1918, Basingstoke: Palgrave, 2017; J. Golinski, 'Humphry Davy's sexual chemistry’ Configurations, 7 (1999) pp.18-41.

10 The term 'scientific mind' overlaps in some ways with Barton's characterisation of 'philosophers of science'. See Barton, op. cit. (9) p.110.

11 J. Endersby, 'Escaping Darwin's Shadow', History of Biology, 36 (2003) pp.385-403.

12 P. White, 'Darwin's Emotions: The scientific self and the sentiment of objectivity', Isis, 100 (2009) pp. 811-826. . A.

Harley, Autobiologies. Charles Darwin and the natural history of the self, Lewisburg: Bucknell University Press, 2015, p.xi.

${ }^{13}$ C. Darwin, 'Recollections of the Development of my Mind and Character', in M. Neve \& S. Messenger eds, Charles Darwin: Autobiographies, London: Penguin, 2002, p.6, p.72. As well as writing consistently for over two months,

Darwin returned to the text, with corrections and additions, most notably in 1879. 
14 'Scientists', as Sleigh put it, 'are textually constructed entities'. C. Sleigh, 'Writing the Scientific Self: Samuel Butler and Charles Hay Fort', Journal of Literature and Science, 8 (2015) pp.17-35, p.19.

${ }^{15}$ F. Darwin ed., The life and letters of Charles Darwin, including an autobiographical chapter, London, 1887, 3 vols.

${ }^{16}$ Darwin, op. cit. (13), p.6.

${ }^{17}$ For the first unabridged version of this text see, C. Darwin, The Life of Erasmus Darwin, Desmond King-Hele ed., Cambridge: Cambridge University Press, 2003.

${ }^{18}$ J. Browne, Review of Charles Darwin's the Life of Erasmus Darwin by Desmond King-Hele. Notes and Records of the Royal Society of London, 57 (2003) pp.346-348. As Browne notes: 'few scholars have until now taken much account of the remarkable fascination that must surely accompany Charles Darwin's assessment of his grandfather'. p. 346.

${ }^{19}$ B. Kuhn, Autobiography and Natural Science in the Age of Romanticism: Rousseau, Goethe, Thoreau, Farnham: Ashgate Press, 2009 pp.1-2

${ }^{20}$ Kuhn, op. cit. (19), p.7. See also L. Marcus, Auto/biographical Discourses: theory, criticism, practice, Manchester: Manchester University Press, 1994.

${ }^{21}$ Sleigh, op. cit. (14), p.19; M. Shortland and R. Yeo, 'Introduction' in Shortland and Yeo (eds), Telling Lives in Science: Essays on Scientific Biography, Cambridge: Cambridge University Press, 1996, pp.1-44, p.4.

22 C. Babbage, Passages from the Life of a Philosopher, London: Longman, 1864, pp.vii-viii; p.485.

${ }^{23}$ W. Shumaker, English Autobiography: its emergence, materials and form, Berkley: University of California Press, 1954 p. 90 .

${ }^{24}$ H. Spencer, An Autobiography, New York: D. Appleton and Co., 1904, 2 vols, vol. I, p.vii. The autobiography that appears to have been most heavily influenced by Darwin, in its consideration of the subject's mental development, was Alfred Russel Wallace's My Life; A record of events and opinions, London: Chapman and Hall, 1905, 2 vol.s.

25 This was then doubled in length by the insertion of the lengthy addendum on scepticism in 1879 , see below..

26 Darwin, op. cit. (13), p.86.

${ }^{27}$ Darwin, op. cit. (13), p.6.

${ }^{28}$ G. Levine, Dying to know. Scientific epistemology and narrative in Victorian England, Chicago, Chicago University Press, 2002 pp.93-94; R. Colp, 'Notes on Charles Darwin's “Autobiography”, Journal of the History of Biology 18 (1985) 357-401, at p.400. See also C. Schmitt, Darwin and the memory of the human. Evolution, savages, and South America, Cambridge, Cambridge University Press, 2009 p.36.

${ }^{29}$ Levine, op. cit. (28), p.2.

30 'Throughout his life, for deep psychological reasons, Darwin found it necessary to depreciate his abilities and to project himself as a slow worker of moderate abilities ...' S.S. Schweber, 'The Genesis of Natural Selection - 1838: Some Further Insights', Bioscience, 28 (1978) 321-326 
31 Sleigh, op. cit. (14), p. 19.

${ }^{32}$ Darwin, op. cit. (13), p.85.

${ }^{33}$ It is not quite correct to claim, as Helsinger did, that Darwin did not share the mid-Victorian concern with honesty in autobiography, rather Darwin's doubts on the efficacy of an evolved rather than lapses of memory or moral shortcomings. H. Helsinger, 'Credence and Credibility: the concern for honesty in Victorian Autobiography' in G. P. Landow (ed.), Approaches to Victorian Autobiography Athens: Ohio University Press, 1979, pp.39-63, p.50.

34 A. Comte, Introduction to Positive Philosophy, Indianapolis: Bobbs-Merrill, 1988, p.21.

${ }^{35}$ H. Maudlsey, Physiology and Pathology of Mind, London: Macmillan and co., 1867, p.44. In the three years he spent preparing to write Descent Darwin read widely, including Maudsley's Physiology and Pathology of Mind and was impressed sufficiently to engage the young, psychiatrist in correspondence. Darwin was even more taken with Maudsley's next book, Body and Mind (1870), which he read as part of his preparation for Expressions of the Emotions in Men and Animals (1872).

${ }^{36}$ Comte, op. cit. (34), p.21.

${ }^{37}$ G. H. Lewes, The study of psychology, its object, scope and method, London: Trubner and Company, 1879, p.82. Lewes was explicitly critical of Comte on this point, p.89: 'The fact is that the mind does observe its operations and precisely in the same way that it observes any other operations. Because they are felt and re-felt under varying conditions, and are capablty of being discriminated, classified, generalized, and experimentally modified, they are data for scientific constructions'.

38 'The mind cannot grasp the full meaning of the term of a million or hundred million years, and cannot consequently add up and perceive the full effects of small successive variations accumulated during almost infinitely many generations'. C. Darwin, 'Essay of 1844' in F. Darwin ed., The Foundations of the Origin of Species. Two Essays written in 1842 and 1844, Cambridge: Cambridge University Press, 1909, pp.248-249.

${ }^{39}$ Darwin, op. cit. (13), p.54.

${ }^{40}$ We should not be misled by his claim that he undertook the 'Recollections' in the expectation it 'would amuse me'. Darwin, op. cit. (13), p.6. Darwin's greatest intellectual breakthrough was the result of reading Malthus 'for amusement' - and writing the 'Recollections' was no frivolous undertaking. As well as writing consistently for over two months, Darwin returned to the text in 1879 to supplement the text with two lengthy addenda.

${ }^{41}$ Comte, op. cit. (34), p.1. See J. Lubbock, Pre-historic Times, as illustrated by ancient remains, and the manners and customs of modern savages (London, 1865). Darwin praised Haeckel’s Genérelle Morpholpogie (1866) and his Natürliche Schopfungsgeschichte (1868) in the introduction to the Descent. C. Darwin, The Descent of Man, and selection in relation to sex, London: John Murray, 2 vols, vol. I, p.4. 
42 ‘[G]radually I gave up my gun more and more, and finally altogether to my servant, as shooting interfered with my work, ... I discovered, though unconsciously and insensibly, that the pleasure of observing and reasoning was a much higher one than that of skill and sport. The primeval instincts of the barbarian slowly yielded to the acquired tastes of the civilized man'. Darwin, op. cit. (13), pp.43-44.

${ }^{43}$ Darwin, op. cit. (13), pp.78-79.

${ }^{44}$ This was pursued most obviously in Descent and the Expression, but also, to some extent, in later works such as Insectivorous Plants (1875), The Power of Movement in Plants (1880), and even in The Formation of Vegetable Mould through the Action of Worms, with Observations on their Habits (1881). This final work included a 32-page section beginning with 'Intelligence Shewn by Worms in Their Manner of Plugging up their Burrows', and shows that worms “possess some elegance of intelligence”. C. Darwin, Vegetable Mould through the Action of Worms, London: John Murray, 1881, pp.92-93.

${ }^{45}$ Darwin, op. cit. (41), I, p.106.

${ }^{46}$ C. Darwin, ‘An autobiographical fragment. Life. Written August - 1838' in Darwin, op. cit. (13), pp.1-5. See also, R. Colp, “I was born a naturalist”: Charles Darwin's 1838 notes about himself”, Journal of the History of Medicine and Allied Sciences, 35 (1980) pp.8-39.

${ }^{47}$ Darwin, op. cit. (13), p.32, p.36, p.22.

${ }^{48}$ Darwin, op. cit. (13), p.20.

${ }^{49}$ Darwin, op. cit. (13), p 88. In the Descent of Man, Darwin had argued that science benefited from a group of men 'who have not to labour for their daily bread'. Dar win op. cit. (41) I, pp.169-170.

${ }^{50}$ Darwin, op. cit. (13), p.88.

${ }^{51}$ Maudlsey, op. cit. (35), p.45.

52 Maudsley, op. cit. (35), pp.131-134.

${ }^{53}$ Darwin, op. cit. (13), p.43.

${ }^{54}$ A. von Humboldt, Personal Narrative of Travels to the Equinoctial Regions of the New Continent during the years 1799-1804, London: Longman, 1814, p.xlvii, p.273.

${ }^{55}$ A. von Humboldt to C. Darwin, 18 Sept. 1839. DCP-LET-534

${ }^{56}$ For example, C. Darwin to R. Patterson, 12 Nov. 1857. DCP-LETT-2168; C. Darwin to G. W. Child, 6 May 1868. DCP-LETT-6162; C. Darwin to A Reuter, 2 June 1869. DCP-LETT-6772.

${ }^{57}$ Darwin, 'Recollections', p.69, p.85. Babbage also compared his mind to a machine, but without of Darwin's apprehension that this might be a negative. Babbage, Passages, p.59

${ }^{58}$ C. Darwin to W. B. Tegetmeier, 20 June 1862. DCP-LETT-3612

${ }^{59}$ Darwin, 'Recollections', p.66. Late in life Leonard Darwin claimed to remember 'the visits of Carlyle to Charles Darwin, when the latter awaited none too anxiously "the crotchety old grouch”“. L. Griggs, 'A scholar goes visiting', Quarterly Review: A Journal of University Perspectives, 40-41 (1934) pp.408-415, at p.411. 
${ }^{60}$ Darwin, op. cit. (13), p.19.

${ }^{61}$ M. Goodmam, 'Nature vs. Naturalist: paths diverging and converging in Edmund Gosse's Father and Son', Life Writing, 11 (2014) pp.85-101, p.86. On Darwin's 'rebellion' against his father see L. Krenis, 'Authority and Rebellion in Victorian Autobiography', Journal of British Studies, 18 (1978) pp.107-130.

${ }^{62}$ Darwin, op. cit. (13), p.14. On Robert Darwin, see R. Bates Graber \& L. Pettengill Miles, ‘In defence of Darwin’s father', History of Science 27 (1989) pp.97-102.

${ }^{63}$ Maudsley, op. cit. (35), pp.133-134

${ }^{64}$ Although as Harley notes, it is telling that Darwin manages a reference to Erasmus Darwin in the second sentence of the 'Recollections'. Harley, op. cit. (12), p.31.

${ }^{65}$ Darwin, op. cit. (13), p.19. Darwin did not reach the same conclusion about any of his daughters, although a similar certainty that untutored childhood traits prefigured adult interests is evident in his heartfelt reminiscence of his 'favourite daughter', Annie: 'one singular habit, which, I presume would ultimately have turned into some pursuit; namely a strong pleasure in looking out words or names in dictionaries, directories, gazeteers, \& in this latter case finding out the places in the Map'. C. Darwin, 'Our poor child, Annie' [Darwin's reminiscence of Anne Elizabeth Darwin] (30.04.1851). CUL-DAR 210.13.40.

${ }^{66}$ Darwin, op. cit. (17), p.16, pp.59-60.

${ }^{67}$ Darwin, op. cit. (17), pp.11-12.

${ }^{68}$ See especially, S. Herbert, 'The place of man in the development of Darwin's theory of transmutation, Part I. To July 1837', Journal of the History of Biology, 7 (1974) pp.217-258.

Darwin himself used the phrase 'mental rioting' to refer to some of his own unformulated thoughts in a letter to Hooker ('I did not consider my letter as reasoning, or even as speculation, but simply as mental rioting', but later historians have used it to refer to his extraordinary production of ideas in his Notebooks in 1838. See C. Darwin to J. D. Hooker, 6 May 1847. DCP-LETT-1086.

69 'These two years and three months [2 Oct. 1836 - 29 Jan. 1839] were the most active ones which I ever spent, though I was occasionally unwell and so lost some time'. Darwin, op. cit. (13), p.47.

70 'My theory would give zest to recent \& fossil Comparative Anatomy, it would lead to study of instincts, heredity \& mind heredity, whole metaphysics -`. C. Darwin, Notebook B [Transmutation of species (1837-1838)]. CUL-DAR121, p. 228 .

${ }^{71}$ Even at this early stage he began two books, one on a general theory of evolution, and a second on the evolution of man and mental faculties. The latter work would be held in abeyance, pending the success of the first'. P. H. Barrett \& H. E. Gruber, Metaphysics, Materialism, and the Evolution of Mind. Early Writings of Charles Darwin. Transcribed and Annotated by Paul H. Barrett. With a Commentary by Howard E. Gruber, Chicago: Chicago University Press, 1974, p.xix. 
72 'In the distant future I see open fields for far more important researches. Psychology will be based on a new foundation, that of the necessary acquirement of each mental power and capacity by gradation. Light will be thrown on the origin of man and his history'. C. Darwin, On the Origin of Species by means of natural selection, or the preservation of favoured races in the struggle for life, London: John Murray, 1859, p.488.

${ }^{73}$ Herbert, op. cit. (68), p.226.

${ }^{74}$ C. Darwin, Notebook $M$ [Metaphysics on morals and speculations on expression (1838)] CUL-DAR125. p.2.

75 ''I have heard my Father say that he believed that persons with powerful minds generally had memories extending far back to a very early period of life'. Darwin, op. cit. (13), p.6.

${ }^{76}$ Darwin, op. cit. (74), p.1.

${ }^{77}$ Darwin, op. cit. (74), p.25.

${ }^{78}$ Darwin, op. cit. (74), p.156.

79 The other two were 'Tendency to small change especially with physical change' and 'Great fertility in proportion to support of parents'. C. Darwin, Notebook E [Transmutation of species (10.1838-7.1839)] CUL-DAR124, p.58.

${ }^{80}$ Darwin, op. cit. (74), p.123.

${ }^{81}$ Darwin, op. cit. (79), p.89.

${ }^{82}$ See K. Holterhoff, 'The history and reception of Charles Darwin's hypothesis of pangenesis', Journal of the History of Biology, 47 (2014) pp.661-695.

${ }^{83}$ C. Darwin, The Variation of animals and plants under domestication, London: John Murray, 2 vols, vol. II, p.28.

${ }^{84}$ C. Darwin, The Expression of Emotions in man and animals, London: John Murray, 1872, pp.265-267.

${ }^{85}$ C. Darwin to J. D. Hooker, 17 March 1863 DCP-LETT-4048.

${ }^{86}$ J. D. Hooker to C. Darwin, 24 March 1863 DCP-LETT-2027.

87 'I somehow blundered \& mentally took literally that the child inherited from his grandfather: this view of latency collects a lot of facts_-both secondary sexual character in each individual—-tendency of latent character to appear temporarily in youth - effect of crossing in educing latent character \&c.- When one thinks of a latent character being handed down hidden for a thousand or ten-thousand generations \& then suddenly appearing, one is quite bewildered at the host of characters written in invisible ink on the germ.- ' C. Darwin to J.D. Hooker, 26 March 1863 DCP-

LETT-4061.

${ }^{88}$ Darwin, op. cit. (83), I, p.335, p.346, p.384;, II, p.6, p.17, p.19, p.230, p.264.

${ }^{89}$ Darwin, op. cit. (74), p.132e, even uses the phrase 'Descent of Man' with capitals.

${ }^{90}$ On Darwin's consistent interest in the problems of mind and inheritance see R. J. Richards, 'Darwin on Mind, Morals, and Emotion' in The Cambridge Companion to Darwin, eds. J. Hodge and G. Radick, Cambridge: Cambridge University Press, 2003, pp. 92-115. Darwin had never abandoned his earlier psychological interests entirely. As he explained in a letter to Wallace at the end of 1857 , man always remained 'the highest \& most interesting problem for the naturalist', Darwin to Wallace, 22 Dec. 1857, DCP-LETT-2192. 
${ }^{91}$ Rather than man, almost immediately after publishing the Origin, Darwin became captivated by the plant species Drosera. Darwin, op. cit. (13), p.75, p.79, p.80.

92 H. Gruber, Darwin On Man: A Psychological Study of Scientific Creativity Chicago: Chicago University Press, 1981, pp.177-179.

${ }^{93}$ C. Darwin, Notebook $N$ [Metaphysics and expression (1838-1839)] CUL-DAR126, p.49. Gruber, op. cit (92) pp. 179-180.

${ }^{94}$ According to Robert Young, nineteenth century theories of the mind owed much to "the general climate of evolutionary thinking' for which Darwin was 'primarily responsible', but Darwin himself 'was somewhat naive in his approach to psychology', and left the heavy lifting to others. Robert M. Young, Mind, Brain and Adaptation in the Nineteenth Century, Oxford: Oxford University Press, 1970, p.191.

${ }^{95}$ Gruber, op. cit. (92), p.219.

${ }^{96}$ A. Desmond and J. Moore, Darwin's Sacred Cause. Race, slavery and the quest for human origins, London: Houghton, 2009, see especially pp.348-376. Harley, op. cit. (12), p.66.

97 The request from an anonymous 'German Editor', which Darwin mentions in the 'Recollections', came from Ernest Von Hesse-Wartegg in 1875. See E. Von Hesse-Wartegg to C. Darwin, 20 Sept. 1875, DCP-LETT-10162.

98 Of course, the process began earlier, in books such as Lewes's Physiology of Common Life, which was published a few months before the Origin, which included a chapter on 'The Qualities We Inherit From Our Parents' which itself drew explicitly on the earlier writings of Lucas, Girou, Moreau, and Lewes's own earlier article in the Westminster Review from July 1856. See R.E Smith, 'George Henry Lewes and His "Physiology of Common Life” 1859', Proceedings of the Royal Society of Medicine, 53 (1960) 569-574. Lewes, like Darwin in his notebooks, considered how vices were exhibited in 'cases where the early death of the parents, or the removal of the children in infancy, prevents the idea of any imitation or effect of education being the cause', and 'the phenomenon of atavism, or ancestral influence, in which the child manifests striking resemblance to the grandfather or grandmother, and not to the father or mother'. G. H. Lewes, The Physiology of Common Life, London: John Murray, 1859, p.385, pp.405-406.

${ }^{99}$ White, op. cit. (12), p.817; Darwin, op. cit. (13), p.79.

${ }^{100}$ Darwin, op. cit. (74), p.53 58, p.96. In the back of the notebook are a series of questions under the heading 'Natural History of Babies'.

${ }^{101}$ C. Darwin, 'A Biographical Sketch of an Infant', Mind, 2 (1877) pp.285-294. H. Taine, 'M. Taine on the Acquisition of Language by Children', Mind, 2 (1877) 252-259. Taine and Darwin's contributions were followed by William Preyer's The Soul of the Child (1882), which arguably provided the foundation text of modern child psychology. 102 Feist, op. cit. (6), pp.23-25

${ }^{103}$ F. Galton, Hereditary Genius, an inquiry into its laws and consequences, London: Macmillan and Co.,1869. F. Galton, 'On the causes which operate to create scientific men', Fortnightly Review, 13 (1873) pp.345-351. ${ }^{104}$ F. Galton, English Men of Science: their nature and nurture, (London, 1874) p.1. 
105 Galton, op. cit. (104), pp.4-5, p.1.

${ }^{106}$ Galton, op. cit. (104), p.193. See V. L. Hilts, ‘ A guide to Francis Galton’s English Men of Science’, Transactions of the American Philosophical Society, 65 (1975) pp.1-85.

107 Galton, op. cit. (104), p.2.

${ }^{108}$ Galton, op. cit. (104), pp.192-193

${ }^{109}$ Galton, op. cit. (104), p.146.

${ }^{110}$ Darwin, 'Recollections', p.20. Darwin borrowed letters from Galton when composing his Life of Erasmus Darwin; in the text noted that he felt sure his half-cousin would 'be willing to attribute the remarkable originality of his mind in large part to inheritance from his maternal grandfather'; and the original introduction was positively Galtonian in asserting the 'public benefit' of adding to mankind's knowledge of inheritance. Darwin, op. cit. (17), p.16, p.7.

${ }^{111}$ Galton, op. cit. (104) p.45. F. Galton, Memories of My Life, London: Methuen and Co. 1908, p.287.

${ }^{112}$ According to Janet Browne, Galton 'pushed “genius” off the romantic mountaintop' with his 'urge to render natural phenomena into numbers that could be tabulated and compared'. Browne, 'Inspiration to Perspiration: Francis Galton's Hereditary Genius in Victorian Context', in Chaplin and McMahon eds. op. cit. (5) pp.77-95, at pp.77-78.

${ }^{113}$ F. Galton to C. Darwin, undated [before 28 May] 1873, in K. Pearson ed., The Life, Letters and Labours of Francis Galton, Cambridge: Cambridge University Press, 1908, vol. 3, pt.2, pp.23-24. Galton, op. cit. (104), p.148.

${ }^{114}$ C. Darwin to F. Galton 28 May 1873, DCP-LETT-8924.

${ }^{115}$ F. Lloyd, ‘A scientific view of Mr. Francis Galton’s theories of heredity', Modern “Science”, 1 (1876)

${ }^{116}$ F. Galton, 'On men of science, their nature and nurture', Proceedings of the Meetings of members of the Royal Institution, 7 (1874) pp.227-236.

${ }^{117}$ In Hereditary Genius (1869), Galton had used the 1861 census and the law of deviations from an average to place men in eight grades of natural ability above (indicated by capital letters) and eight grades below (indicated by lower case letters) the average, in mirror image. Thus grades A and a, either side of the average, both contained 256,741 per million, while $\mathrm{G}$ and $\mathrm{g}$ contained only 14 each. Galton had hoped that his 'men of science' respondents would grade their abilities according to this table for the 'Classification of Men According To Their Natural Gifts', but was forced to drop his plan. F. Galton, Hereditary Genius, an inquiry into its laws and consequences (London, 1869) pp.34-36. 'I also omit the description of a notation I proposed to replace indefinite words such as 'large', 'considerable', because I have made no use of it in this volume'. Galton, op. cit. (104), p.261.

118 Darwin's response to Galton's questionnaire is reproduced in Hilts, ‘A guide’, pp.10-11.

119 D. Stack, 'Charles Darwin's Liberalism in "Natural Selection As Affecting Civilised Nations", History of Political Thought, XXXIII (2012) pp.525-554.

${ }^{120}$ Galton, op. cit. (104), p.33, p.37.

121 S. J. Peart, 'Darwin's unpublished letter at the Bradlaugh-Besant trial: a question of divided expert judgment', European Journal of Political Economy, 24 (2008) pp.343-353. 
122 Darwin, op. cit.(41), I, pp.103-104.

${ }^{123}$ J. Browne, 'Making Darwin: biography and the changing representations of Charles Darwin', The Journal of Interdisciplinary History, 40 (2010) pp.347-373, at pp. 359-361.

${ }^{124}$ Darwin, op. cit. (13), p.20.

${ }^{125}$ Darwin to Galton 3 December 1869, quoted in D. W. Forrest, Francis Galton: the life and work of a Victorian genius, New York, Taplinger, 1974, p.101.

${ }^{126}$ C. Darwin to Samuel Smiles, 15 Dec. 1876 DCP-LETT-10720.

${ }^{127}$ Darwin, op. cit. (13), p.76, p.61.

${ }^{128}$ Harley, op. cit. (12), p.44, p.17.

129 'I have endeavored to keep my mind free, so as to give up any hypothesis, however much beloved (and I cannot resist forming one on every subject), as soon as facts are shown to be opposed to it'. Darwin, 'Recollections', p.86.

${ }^{130}$ Darwin, op. cit. (17), p.60. p.35.

131 See C. Darwin to J. D. Hooker, 3 Nov. 1864. DCP-LETT-4650; C. Darwin to J. D. Hooker, 10 Dec. 1866. DCPLETT-5300.

132 Darwin, op. cit. (13), p.64, p.63.

${ }^{133}$ Galton, op. cit. (104), p. 12.

${ }^{134}$ R. Yeo, Defining Science. William Whewell, natural knowledge, and public debate in early Victorian Britain Cambridge: Cambridge University Press, 1993, p.166. p.31.

${ }^{135}$ R. F. Higgitt, Recreating Newton: Newtonian biography and the making of nineteenth-century history of science, Cambridge: Cambridge University Press, 2007.

136 On Darwin's relationship with Whewell see M. Ruse, 'Darwin’s debt to philosophy: an examination of the influence of the philosophical ideas of John F. W. Herschel and William Whewell on the development of Charles Darwin's theory of evolution', Studies in History and Philosophy of Science, 6 (1975) pp.159-181. 'Dr. Whewell was one of the older and distinguished men who sometimes visited Henslow, and on several occasions I walked home with at night'. Darwin, op. cit. (13), p.35.

137 W. Whewell, Astronomy and General Physics considered with reference to natural theology, London: William Pickering, 1833, Bk III, 'Religious Views'.

${ }^{138}$ See L. J. Snyder, Reforming Philosophy. A Victorian debate on science and society, Chicago: Chicago University Press, 2006, ch. 1 'Whewell and the Reform of Inductive Philosophy', pp.33-94.

${ }^{139}$ M. Somerville, Personal Recollections from early life to old age, of Mary Somerville, with selections from her correspondence by her daughter, Martha Somerville, London: John Murray, 1874, ch. IX.

140 Darwin, op. cit. (13), pp.49-54.

${ }^{141}$ Comte, op. cit. (34), p.6.

${ }^{142}$ L H. Peterson, Victorian Autobiography. The Tradition of Self-Interpretation Yale: Yale University Press, 1986 p.137 
${ }^{143}$ See especially Darwin, op. cit. (13) pp.43-44. 'Darwin writes his youth in terms of who he is as an adult, presenting us with telling or ironic anecdotes about his burgeoning scientific tendencies'. Harley, op. cit. (12), p.9.

${ }^{144}$ Comte, op. cit. (34), p.6. Darwin, op. cit. (13), pp.49-54.

${ }^{145}$ Later, when he was drafting the 'Recollections', it is interesting to note that Darwin chose to place the 'Religious

Belief' section between a short account of his return from the Beagle voyage in October1836 and his marriage in January 1839, confirming that his encounter with Comte's ideas at the very least coincided with the most crucial period in his loss of religious belief.

${ }^{146}$ A. Desmond and J. Moore, Darwin, London: Penguin, 1991, pp.260-261.

${ }^{147}$ Whewell described the three stage theory as 'worthless, and, indeed, absolutely puerile'. W. Whewell, 'Comte and Positivism', Macmillan's Magazine, XIII (1866) pp.353-362, at p.355.

148 C. Darwin to C. Lyell n/d [1 Aug. 1861]. DCP-LETT-3223.

149 S. S. Schweber, 'The origin of the "Origin” revisted', Journal of the History of Biology, 10 (1977) pp.229-316, at p. 250.

${ }^{150}$ Huxley declared: 'Comtism is, in spirit, anti-scientific'. Anon. [T. H. Huxley], 'The scientific aspects of Positivism', The Fortnightly Review, V (1869) pp.653-670, at p.658.

${ }^{151}$ C. Darwin to J. D. Hooker, 24 July 1869. DCP-LETT-6841.

${ }^{152}$ C. Darwin to T. H. Huxley, 10 March 1869. DCP-LETT-6649. C. Darwin to T. H. Huxley, 12 March 1869. DCPLETT-6658.

${ }^{153}$ C. Darwin to J. Fordyce, 7 May 1879. DCP-LETT-12041; Darwin, 'Recollections', p.54.

${ }^{154}$ See B. Lightman, 'Huxley and scientific agnosticism: the strange history of a failed rhetorical strategy', Journal of the History of Science, 35 (2002) pp.271-289.

155 Darwin, op. cit. (13), p.86.

156 Darwin, op. cit. (13), pp.86-88.

${ }^{157}$ Darwin, op. cit. (13), p.55.

158 W. K. Clifford, ‘The Ethics of Belief’, Contemporary Review, 29 (1877) pp.289-309.

159 Darwin, op. cit. (13), p.86.

160 Clifford, op. cit. (158).

${ }^{161}$ Feist, op. cit. (6), p.224.

162 Darwin, op. cit. (13), p.86.

163 'May not the habit in scientific pursuts of believing nothing till it is proved, influence your mind too much on other things which cannot be proved in the same way, ...' E. Darwin to C. Darwin, Feb. 1839. DCP-LETT-471. 
164 This reluctance to follow without proof is the leitmotif the section on 'Religious Belief' in the 'Recollections', to the extent that Darwin notes how he had initially hoped to counter his own growing disbelief by 'inventing day-dreams of old letters between distinguished Romans and manuscripts being discovered at Pompeii or elsewhere which confirmed in the most striking manner all that was written in the Gospels', and would allow him to believe. Darwin, op. cit. (13), p.50.

165 Darwin, op. cit. (13,) p.55.

166 Darwin, op. cit. $(13$, p.9.

${ }^{167}$ Darwin, op. cit. (13), p.56.

168 See E. Janes Yeo, 'Will the real Mary Lovett please stand up?: Chartism, gender and autobiography', in M. Chase and I Dyck, eds, Living and Learning: essays in honour of J. F. C. Harrison, Aldershot: Routledge, 1996, pp.163-181. 169 See Mark Francis, Herbert Spencer and the Invention of Modern Life, Cornell: Cornell University Press, 2007 p.73; Maudsley, “Sex in Mind and Education',' Fortnightly Review, 15 (1874): pp.469-71.

170 Darwin, op. cit. (41), II, p.327, p.402.

${ }^{171}$ Darwin, op. cit. (83), II, p.72, pp. 83-84, p.29.

172 Darwin, op. cit. (17), p.16.

173 Galton, op. cit. (104), p.206, p.197.

${ }^{174}$ Galton, op. cit. (104), p.148, pp.206-207, pp.258-259, p.207.

175 Galton, op. cit. (104), p.141.

${ }^{176}$ Darwin, op. cit. (41), II, p.328.

${ }^{177}$ Unlike Galton, his chief disciple, Karl Pearson, did not reject literature either, arguing that it represented human patterns of feeling and behaviour and that science was 'utterly dependent on imagination. The great champion of statistics, then, managed very neatly to merge science and literature in a life devoted to fact and suffused by fiction'. T. M. Porter, Karl Pearson. The Scientific life in a Statistical Age, Princeton: Princeton University Press, 2004, p.311.

${ }^{178}$ Darwin, op. cit. (13), p.69, p.85.

179 Darwin, op. cit. (41), I, p.35.

${ }^{180}$ Galton, op. cit. (104), pp.84-85.

181 'A man with a mind more highly organised or better constituted than mine, would not I suppose have thus suffered'. Darwin, op. cit. (13), p.85.

182 Ellis, op. cit. (9), pp.12-128. 